Cinémas

Revue d'études cinématographiques

Journal of Film Studies

\title{
Oedipality in Red Sorghum and Judou
}

\section{Mary Ann Farquhar}

Volume 3, numéro 2-3, printemps 1993

Le nouveau cinéma chinois

URI : https://id.erudit.org/iderudit/1001192ar

DOI : https://doi.org/10.7202/1001192ar

Aller au sommaire du numéro

Éditeur(s)

Cinémas

ISSN

1181-6945 (imprimé)

1705-6500 (numérique)

Découvrir la revue

Citer cet article

Farquhar, M. A. (1993). Oedipality in Red Sorghum and Judou. Cinémas, 3(2-3), 60-86. https://doi.org/10.7202/1001192ar

\section{Résumé de l'article}

Cet article analyse la représentation de la masculinité dans Sorgho rouge et Judou, deux films réalisés par Zhang Yimou. L'orientation est l'oedipalité, plus précisément le meurtre du " père " réel ou symbolique, comme condition pour la libération du fils et de sa femme / maîtresse. Le texte aborde cette problématique en trois volets : le patriarcat et l'ordre social; le patriarcat et le corps; le patriarcat et la légitimité. Le propos consiste ici à mettre en valeur le fait que l'oedipalité, dans ces films, n'est pas présentée comme une condition psychique "valide universellement » (Freud), mais comme le résultat inévitable du système familial patriarcal. 


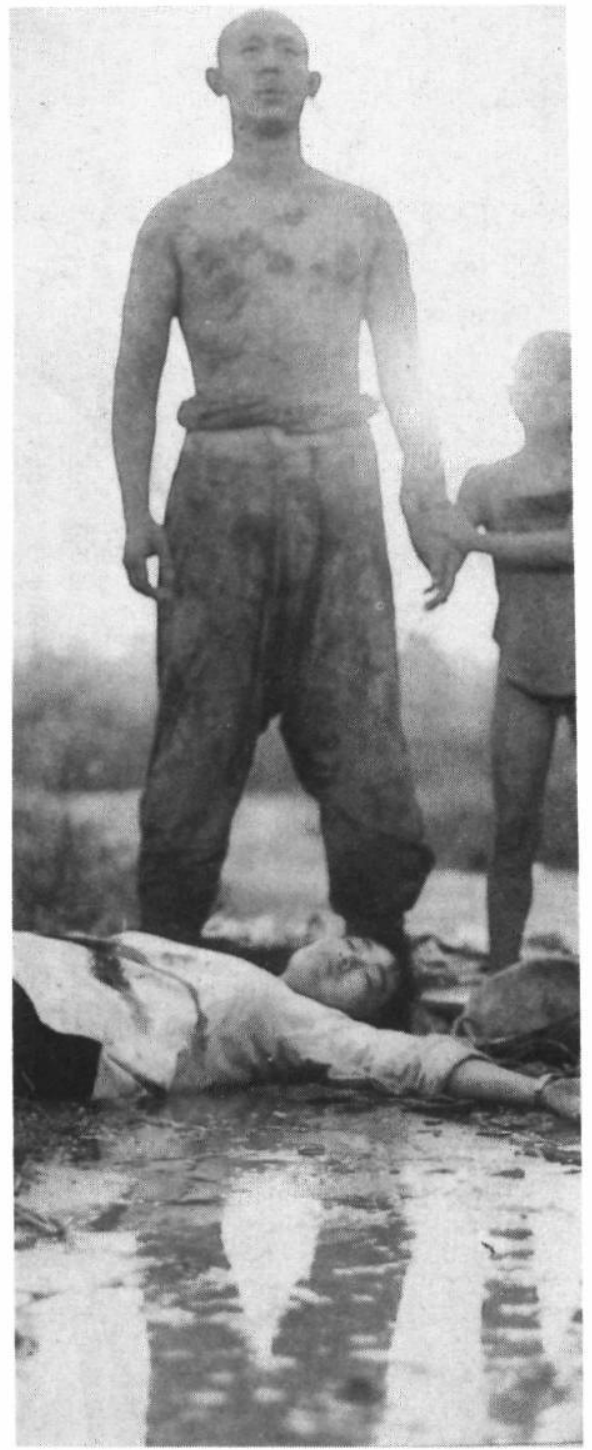

Sorgho rouge de Zhang Yimou (1987) 


\title{
Edipality in Red Sorghum and Judou ${ }^{1}$
}

\section{Mary Ann Farquhar}

\section{RÉSUMÉ}

Cet article analyse la représentation de la masculinité dans Sorgho rouge et Judou, deux films réalisés par Zhang Yimou. L'orientation est l'œdipalité, plus précisément le meurtre du "père» réel ou symbolique, comme condition pour la libération du fils et de sa femme / maîtresse. Le texte aborde cette problématique en trois volets : le patriarcat et l'ordre social; le patriarcat et le corps; le patriarcat et la légitimité. Le propos consiste ici à mettre en valeur le fait que l'œdipalité, dans ces films, n'est pas présentée comme une condition psychique «valide universellement» (Freud), mais comme le résultat inévitable du système familial patriarcal.

\begin{abstract}
This article analyses the representation of masculinity in Red Sorghum and Judou, two films directed by Zhang Yimou. The focus is on odipality, in particular the murder of the real or symbolic "father" as a condition for the liberation of the son and his wife / mistress. The text is divided into three sections : patriarchy and the social order; patriarchy and the body; and patriarchy and legitimacy. The argument is that œdipality in these films is not presented as a "universally valid" psychic condition (Freud) but as an inevitable result of the patriarchal family system.
\end{abstract}


Red Sorghum (Hong gaoliang,1987) and Judou (1989) are the first two films directed by one of China's most famous filmmakers, Zhang Yimou. Visually sensual and colourfully lavish, Red Sorghum stunned Chinese film audiences and Judou was banned by the authorities for their depiction of overt sexuality. ${ }^{2}$ For the first time in post 1949 films, individual sexual desire is seen as fundamental to social relationships and the social order. Red Sorghum's celebration of peasant vitality is said to have created "a powerful Chinese version of masculinity" and "a new version of female sexuality" (Wang, 85, 93). The mythic and idyllic qualities of Red Sorghum were qualified by the dark side of Chinese sexuality presented in Judou two years later.

Like the stories in both films, most reviews concentrate on the heroine's life between a traditional marriage and premature death within the family system. The emphasis is on gender and particularly sexual relations. The more analytical reviews are read against a Chinese background, both Confucian and Communist, which privileged masculinity over feminity and repressed female desire as subversive of patriarchal power. This is the familiar yin (female) and yang (male) dichotomy so central to the dominant Confucian discourse on power relationships within the family as a microcosm of the state and cosmic order. Male ascendancy was traditionally read as natural and therefore moral law. Red Sorghum flouts this law and leads to fulfilment and an egalitarian social order until destroyed by Japanese invasion. It celebrates life. Judou, conversely, perpetuates this law and leads to repression, perversion and, finally, patricide. It documents death. The films, therefore, are situated within the twentieth century critique of feudal patriarchy.

Sexuality is central to any analysis of these films. But a focus on masculine sexuality, rather than the feminine or sexual relations, suggests that the central tension in the films when read together is between "father" and "son", not men and women. Masculinity is sexually defined around two concepts : (exclusive) possession of a young woman and fertility, or the birth of sons. In both Red Sorghum and Judou, this woman is the legitimate property of old and "impotent" husbands; the sexually incompetent monopolize the sexually desirable. Escape through a younger male leads to hostility and actual or symbolic patricide. Edipality is not desire for the mother but desire for the power and possessions of the "father", realized in his absolute and exclusive control over his women, whether daughter or wife. Mutual sexual desire validates the younger man's hostility. Sexual ecstasy proves his masculinity. The birth of sons establishes his potency within a Chinese context. 
But this desire is ultimately legitimized or repudiated, in turn, by the son / grandson within the film's diegesis.

Edipality is, therefore, not the Western specificities of Freud's "Edipus complex" as universals in the individual psyche. Edipality is desire for the father's women, not for the blood mother, and resentment of patriarchal power. Ma Junxiang convincingly argues that Zhang Yimou's films set up two images of the father. The "new father" emancipates women, sons and social relationships. The "old" feudal father oppresses women and sons and, depending on the nature of the father, patricide leads to either liberation (Red Sorghum) or ongoing oppression (Judou). As hostility to "law of the father" (fu zhi fa), œdipality is a culturally-induced psychic condition which may, or may not, be overturned (Ma, 123-132). ${ }^{3}$ It is part of a century-long debate on paternal authority which, Lu Xun said, is "absolute" and "sacrosanct". He called on fathers themselves to change :

Burdened as a man may be with the weight of tradition, he can yet prop open the gates of darkness with his shoulder to let children through to the bright, wide-open spaces, to lead happy lives henceforth as rational human beings. (Farquhar, 38-39) 4

In this debate, light is liberation and darkness is paternal authority. Liberation is natural; patriarchy is unnatural. This opposition is part of Chinese critiques of Zhang Yimou's films. Red Sorghum, with its motif of sorghum wine, is said to celebrate a mythic Dionysian life force and vibrant masculinity (Chen, 3031). Judou, conversely, is likened to an "inexorable" Greek tragedy in which diseased masculinity is passed down through generations of a feudal family, obsessed with sons (Yin, 35). ${ }^{5}$ Mutual fear between father and son is the personal and public œdipality of Sophocles' Edipus Rex, in which attempted murder is initiated not by the son but by the father. Kwok Wah Lau calls this the "inverse œdipus complex" in Chinese mythology, in which the father kills the son in line with the tradition of xiao or filial piety (8). 6 This is, however, a false "inversion" for the œedipal story, which Freud re-read as a universal of the human condition, does begin with the attempted murder of the son. The resulting "inexorable" tragedy of hubris and the curse of the gods is passed through three generations from Laius to Edipus and his children. In CEdipus Rex, patricide is one symptom of warped generational relationships in one royal family. In Judou, patricide is the result of the feudal family system itself. In Zhang Yimou's films, patricide is the inevitable curse of patriarchy. 
Red Sorghum is free and unfettered, Judou is the other side of the same coin (Zhang Yimou). ${ }^{7}$

The opening scenes of both films immediately establish old husbands as emblems of darkness and omens of death. They are in fact caricatures of feudal husbands whose power was not, in fact, absolute and who bore complex familial and legal responsibilities with fixed punishments and religious sanctions. In Red Sorghum and Judou, Big Head $\mathrm{Li}$ and Yang Jinshan as the respective husbands are embodiments of evil. They take, or more literally buy, a beautiful virgin. The Chinese character for marriage by a male is $q u$, made up of the radical nü for woman and $q u$ to take, which is a picture of a hand and ear. These old men in the films forcibly take, or attempt to take, an unwilling young girl. The character for a girl's marriage is jia which again has the female radical and the character, jia, meaning family. "Family" is a pictograph of a pig under a roof. Morally, legally, socially, sexually and even linguistically, a wife is "taken" and "taken into" an alien family for production, just like the pig. Her production is sons. The ancient pictograph for women sketches her reproductive outline in a ritually submissive pose. The social significance of this is that the character for "good" (hao) as against evil in Chinese is a picture of a woman and son. It signifies not just family propriety but a proper social order.

In both films, a young girl is unwillingly taken into the house of an old and unknown man. In Red Sorghum, the erotically beautiful face of the heroine, Jiu'er, emerges from darkness decorated in bright red, then totally covered by a red veil and finally confined alone to a red bridal sedan chair to be carried to her husband's home. Red traditionally symbolized both marriage and masculinity. For Jiu'er it symbolizes death. Like the written characters, marriage has a different meaning for women. The sedan chair carriers discuss the marriage.

Ergouzi :

Elder Brother :

Grandfather :

Grandfather, Ergouzi :

Grandfather :
Whose daughter is she?

Her parents are cruel, they only care about money.

Big Head $\mathrm{Li}$ is full of pus, he's on the way out.

Don't let him touch you. If he does you'll rot!

If you change your mind, there is still time to go back (Bush, 48-49). 8 
They then jostle her in the sedan, singing a ribald song about her husband's leprosy, ugliness and the wedding night. Jiu'er breaks two marriage taboos voiced off-screen. "Don't cry in the sedan, it will bring you bad luck. Don't lift the veil, it will get you into trouble." She lifts the veil, rejecting confinement. She cries when she hears about her husband, welcoming trouble (Bush, 49-50). When a bandit attempts to abduct her, she smiles; she prefers him to Big Head Li. Grandfather's young strength and manliness, glimpsed through the sedan curtains, is a striking visual contrast to the verbal imagery of disease and death. It is grandfather who leads Jiu'er from confinement to "the bright... open spaces" of Lu Xun's vision. Their desire is consummated in a sun-filled sorghum field and Grandfather then allegedly kills Big Head Li.

Judou begins with the return home of Yang Tianqing, the adopted nephew/son of an owner of a dye factory, Yang Jinshan. The camera moves from a full shot of the surrounding muted countryside, to the grey and white village and, finally, to the massive gates and interior of the factory. The old husband's surname, although a different character, is a homonym of yang or the masculine principle. Yang's cruelty is shown by his aggressive authority over Tianqing and his meanness to a temporary worker over pay. The worker then tells Tianqing that Yang has paid a lot of money for a third wife. The other two were tortured to death for failing to provide sons. His eyes light up as he says, "You can hear her screaming at night" as the old man sexually tortures her. We then hear her screaming through the dark and see her being beaten. Thus, the heroine, Judou, and Tianqing are respectively victims of physical and emotional abuse. They are literally treated as animals, family chattels like the screaming pig Yang kills, to be evaluated by their labour. Judou's seduction of Tianqing, like the marital rapes, takes place inside until, finally, they make love in an underground, unlit, airless tunnel. But Tianqing never dares kill his uncle. Judou is a trip back through Lu Xun's "gates of darkness" to a family confined and controlled by vicious patriarchal power.

Zhang Yimou himself saw these two films as complementary opposites : the way we should be and the way we were. He said, they "are sister films, but the sisters are not at all alike" (Woodman, 34). Judou concentrates on the patriarchal family system which is "murdered" at the beginning of Red Sorghum as a precondition for the characters' liberation. Seen together, these films suggest that fulfilment is only possible by subverting patriarchy which disempowered the young male and dispossessed the female of sexuality. Judou clarifies what Red Sorghum 
implies: murder of the "old father" is the only way for masculine empowerment and feminine emancipation. In China, this reading of patriarchy as vicious and diseased has contemporary political implications for China's gerontocracy.

The real reason Judou was unacceptable to the Party is because it depicts a brutal, despotic old man who rules his family through [systematic] physical and emotional violence, an allusion to the hostility between Chinese society and its aged leadership. (Qiu, 79)

As opposites, these films are structured around images of light and dark, informed by dualisms within traditional and modern patterns of thought. Zhang Yimou's strength is his emphasis on visual imagery, and particularly colour, as cinematic language. But he plays with these dualisms to reinforce the critique of patriarchy. The most obvious, as we said, is the evocation of yang / yin symbolism which evokes the oppositions of light / dark, sun / moon, sky / earth, warmth / water and red / black. In Chinese thought, these opposites contain each other and are supposed to harmonize. As I have suggested, "exploration of a specific space", outdoors or inside at the beginnings of the films, "is simultaneously landscape, culture and metaphysics" (Reynaud, 27). The wild sorghum itself, which surrounds the action and makes a living in Red Sorghum, symbolizes a rich and natural fecundity, "free and unfettered" relationships, a merging of sun and earth, of yang and yin. Judou presents "the other side" : the forbidding walls and massive gate of the factory is a visual image of the "crushed, atrophied" relationships in a patriarchal family where yang rules to the exclusion of all else. In China, where the family has always been a metaphor for the state, these two symbolic worlds of light and dark, harmony and chaos, represent two opposing social orders: freedom and oppression. Freedom is "natural"; oppression is "unnatural".

This opposition reverses the traditional Confucian invocation of natural law as the foundation of social order. The Qianlong Emperor asserted that "the child's [inferior] relationship to the parents derives from Heaven" (Bodde, 362). A woman, like a child, was also inferior to her husband. The nurturing mother embodied the feminine ideal, while dangerous sexuality could "suck out man's vital energy during intercourse" (Schak, 62) or cause chaos in the state. Empress Wu and Jiang Qing are two examples. In Zhang Yimou's films, female submission required for the maintenance of patriarchy is seen as unnatural. The heroine, played by the beautiful Gong $\mathrm{Li}$, exudes a sometimes sizzling, sometimes sultry sensuality which is depicted as natural. 
This sensuality resonates even in the later part of both films when motherhood and tragedy mute and transmute her desirability. The contradictory stereotypes of women as mother or vampire are collapsed in Zhang Yimou's films to a single, sympathetic female character.

Whereas the heroine embodies all female roles - daughter, wife, lover, mother, grandmother - the men's roles are differentiated. Hence, masculinity is more complicated and more problematic. The male characters responses to the heroine range from the mythically "natural" love, called a "wild coupling" (yehe) in Red Sorghum to the most "unnatural" of all acts in Chinese law and morality, patricide, in Judou. Patricide in Red Sorghum is symbolic. In Judou it is an actual double murder of his official and blood father by an adolescent boy. He enjoys it. It is the only time we see him smile.

The reading of masculinity in these films rests on their recuperation of two powerful anti-Confucian traditions in Chinese thought. Despite the supposed passivity of Daoism, ancient Daoists were violently opposed to the Confucian moral hierarchy and narrow concern with social propriety. They rejected notions of patriarchy, hierarchy and righteousness. Confucian and Legalist thought was "masculine and managing" with leadership from above; Daoists embraced the "feminine and tolerant" with leadership from within : "it was suited for, and in a real sense the poetical expression of, a cooperative collectivist society" (Needham, 59). Daoism emphasized spontaneity, not passivity. In Chinese, "spontaneity" is ziran or naturalness and "Nature" is $d a$ ziran (big naturalness). Needham suggests that the maxim "nonaction" (wuwei) would be better translated as "refraining from action contrary to nature" (68). Untrammelled natural action included the equality of yin and yang and mutual sexual nourishment for health and longevity. "Buddhist asceticism and Confucian prudery were scandalized" by Daoist sexual practices $(151)^{9}$, which were theorized as cosmic union, but repression was never fully successful as these films attest. Chinese Communism equally repressed desire as individualistic and therefore inimical to the notion of collectivity which grounded its authority. Red Sorghum returns the Daoist experience of sexuality as "pure joy" and equality to the people. Judou exposes sexual union in the marriage market as literally barren and brutal. Virility, shot through with red, versus a black sterility in the language of these films.

The power inequality between generations, especially father and son, was the focus of a second wave of anti-Confucian thought 
in modern China. Social Darwinism in the early twentieth century was used by revolutionaries to attack Confucian hierarchies as unnatural, unscientific and contrary to the law of survival. Added to this were European notions of childhood innocence corrupted by civilization, which was read as Confucianism in the Chinese context. Both echo the Daoist critique. Experts have commented on the similarities of Daoist works to the theory of evolution and to the writings of Romantics, such as Blake $(154,162)$. The Romantics praised child-like innocence while Daoist techniques stressed a return to the newborn child (163). Thus, for Lu Xun who among others represented this view in the early May Fourth period, the father's emancipation of the young is "the road of evolution",10 leading to survival and happiness. This meant China's survival because "the future is the era of our sons and grandsons" (Lu Xun, 70). Sexual desire was seen as part of this natural, uncorrupted world. Red Sorghum celebrates sexuality within a modern egalitarian sensibility. Judou represents Lu Xun's mirror picture of "a suicidal turning back" to the madness and superstition of paternal power, institutionalized in the social order. This order, perpetuated from generation to generation, is "man-eating" rather than an order of "real men" (zhenren, a term borrowed from Daoism). The murderous son in Judou is the chilling, unnatural issue of a diseased society. This reading of œdipality as systemic is not abstruse; Lu Xun's works were part of the school curriculum, even during the Cultural revolution period, and therefore part of the literary canon in post-1949 China that underpins both literature and its readings.

Lu Xun, like the early Communists, argued that enlightened fathers must emancipate their children for the sake of the future. Zhang Yimou's films suggest that entrenched patriarchy will never give away power. The young themselves must wrest this authority as total possession, not as petty pilfering. 11 Grandfather publicly takes over the leper's wife, bed, winery and workers. Tianqing lives furtively in his "father's" house with his father's wife but can never acknowledge his son. Public acknowledgment of young masculine power is crucial. Acknowledgment works at various levels: sexual, familial and social.

\section{Patriarchy and the Body: Sexuality and Fertility}

If the yang force in man was continually fed by the yin force, it would not only conduce health and longevity, but its intense maleness would ensure the sex of the resulting child would be male. Continence was considered not only impossible, but improper... Celibacy...would produce only neuroses. (Needham, 149) 
Fertility and eroticism are central to an understanding of sexuality in both Red Sorghum and Judou. As with marriage, sexuality is a gendered experience. This is also inscribed in the Chinese written language and part of the Chinese discourse on sexuality. The character for sex is xing, a marrying of heart and birth, which is a pictograph of a plant rising out of the earth, symbolizing vegetal growth. Xing incorporates feelings and fertility. Yin and yang xing denote female and male gender, respectively. The word for intercourse, xingjiao, literally means an exchange of xing, a cross-fertilization of yin and yang. Seminal essence (shen) mingled with the female germinal essence (ling), producing harmony and growth likened to "rain" (269). In ancient Daoist theories, sexual harmony between yin and yang led to joy, health, longevity and immortality. When the mythical Yellow Emperor's favourite concubine heard of Daoist sexual techniques, she said, "Not to struggle against one's natural desires and attain longevity, what joy!" (Beurdley, 8).

The patriarchal discourse on sexuality appropriated Daoist sexual rituals and philosophy within a science, an "internal alchemy", of male ascendancy. Yang essence was finite and could be drained by yin, causing illness and death. This physically revitalized the woman and exhausted the man. Sexual technique therefore clustered around methods of using female orgasm to strengthen man's vital powers, particularly by reserving ejaculation (10). 12 When yang was vital, sons were born. In this erotic science, men could sicken and die through an excess of yin, symbolized as water. The Daoist term for sexual domination by yang was "clouds and rain" (yunyu) whereas harmony was "rain", a fertile mingling of fire (male) and water (female). From the third century A.D. however, "clouds and rain" originally signifying disharmony and male ascendancy (Needham, 269), 13 became the common and positive poetic expression for intercourse. Thus, patriarchy was inscribed in the terminology, techniques and alchemy of sexuality, channelled toward the birth of sons as well as health and longevity. Sexuality was gendered to disempower women. The nurturing female, as mother, nourished the male. The sexually aggressive female sucked out man's vital fluids like a vampire.

Red Sorghum draws on the early Daoist discourse whereas Judou is situated within patriarchal notions of sexuality. Old men are infertile and impotent. Young men are virile and fertile. The construction of sexuality in these films reiterate images of health and disease as a cultural typology of masculinity. 
The leprous husband in Red Sorghum is never shown on-screen. We are told he is lethally contagious and sexually incompetent; he cannot consummate his marriage because Jiu'er defends herself with a scream and scissors. While this is happening, the camera focusses on a quiet Luohan who as foreman of the winery is a nurturing, productive older male. Age alone does not signify disease. Unlike the original story, he is not Jiu'er's lover but helpmate who leaves when Grandfather claims Jiu'er. Conversely, Yang Jinshan in Judou is a constant and powerful on-screen presence until his death. We see him sitting astride his bound and saddled wife as he beats her saying, "A wife is like a mule, to be ridden and beaten, ridden and beaten". He threatens death unless she bears a son. But we know the problem is his infertility, not hers. Later he is crippled from the waist down and so both impotent and infertile. In Chinese "if the stalk of jade [penis] is not used, sex dies..." (Beurdley, 15). His masculine authority is barren like his body within a Chinese context.

The young men in Red Sorghum are variously valorized according to their nurture of Jiu'er. She is abducted by two bandits: a masked bandit and the fearsome Sanpao, who does not rape her because he fears she has slept with the leper. Grandfather saves Jiu'er from the masked bandit and confronts Sanpao in his lair for allegedly "ruining" his woman. He protects Jiu'er; his sexuality includes the heart. This is the nurturing framework in which he abducts and makes passionate love to her in the wild sorghum, consummating a "marriage" and begetting a son. Suggestions of rape in Western critiques cannot be sustained by a textual analysis. Bush has convincingly argued that the earlier scenes set up "a sort of marriage based on protection, desire and free choice" (52). The text, which details this abduction and seduction as Jiu'er rides home, is worth quoting at length. Grandfather seizes her in front of her father and from the donkey which Big Head Li paid for her; in short, he takes her from the two old representatives of patriarchy who control her life. The scene then describes adoration and ritual worship between earth and sky:

A masked man crushes out of the sorghum / My grandmother screamed in fear;

The man forced my grandmother off the donkey,

The sorghum flashed before my grandmother's eyes;

The thick sorghum was forced open, then swiftly closed. They disappeared...

Suddenly the man fell. My grandmother struggled and escaped, running for her life;

A desperately fleeing grandmother; A man in hot pursuit.

(Repeat twice)

My grandmother stumbled / My grandmother suddenly stopped; 
The man took off his mask - it was my grandfather!

My grandmother said, "Heaven".

My grandfather's hot blood surged, his eyes burned,

My grandmother's eyes filled with tears;

My grandfather trampled the sorghum,

He trampled the sorghum with his body/ He trampled the sorghum with his feet.

In the sea of green sorghum a space was cleared...

(Full shot) The trampled sorghum formed a round altar in a sea of green. My grandmother lies motionless, facing the sky. My grandfather kneels. 14

As Berry has shown in two different films, the shot-reverse shot does not necessarily signify subject-object but disharmony in the Chinese context (37). Jiu'er, not recognizing Grandfather, fights him. Recognizing him, she stops and the symbolism in his burning eyes and her tear-filled eyes is unmistakable. Quiescence is not submission. When the camera unites previously warring individuals in a single image, according to Berry, harmony is "literally and cinematically" signified in the frame (37). The final full shot of man / woman, earth / sky, sorghum / sun is Daoist cosmic harmony, sexual "supreme joy".

Grandfather is not just potent, he is phallically male. In the early scenes, Jiu'er peeks through the curtains at his "strong muscle-bound back...naked from the waist up...muscles are rippling" (Bush, 73). Their relationship is earthy as well as idyllic; when she rejects and beats him because he is drunk, he complains, "You were different with your pants down". When he comes a second time to reclaim Jiu'er as his "wife" publicly in the winery, he opens his trousers and urinates in the wine vats. As Jung said, "the penis is only a phallic symbol" (Storr, 26). The concave, wine-filled vats are a vaginal symbol. The word for wine, jiu, and Jiu'er's name are homonyms. He then showers Jiu'er with grain (a "rain" of seeds) and again she becomes still as he takes her and moves into the leper's bedroom. Grandfather's urine makes the best red sorghum wine ever produced and is the foundation for the winery's subsequent prosperity. It is at this point that Luohan leaves. Grandfather's potency is bawdily sexual and commercial.

While Grandfather's body is revealed and physical, Jiu'er's is concealed, except for her face. It is men's bodies which visually do the work, bear the disease and are skinned alive by Japanese soldiers. While they work, she watches and decorates, both literally and figuratively. Even though she decides on revenge against the Japanese, men go to fight while she cooks and she dies taking them food. Zhang Yimou "cleaned [her] up" from the "wild, unruly" promiscuous woman in the book to the "pure" 
woman because he liked this image better. He wanted her relationship with Grandfather to seem "lofty", not "dirty" (Zhong, 47). ${ }^{15}$ In the best feudal tradition, she is a virgin, a state of grace which in the modern literature is called a girl's "most precious thing." 16 It is her face which expresses sensuality and is often shown rapturous and eroticized. One foot in red embroidered wedding shoes, a sexual symbol in Chinese erotica more intimate in practice than the vulva, is seized by the bandit. She then offers one tantalizing foot outside the sedan curtain after Grandfather saves her but he gently takes it and hides it behind the curtain. $\mathrm{He}$ is protective but also keeps her for himself.

Sexuality in Judou is primarily described through colour in Judou's clothes and the vibrant rolls of dyed cloth which hang suspended in the factory. These encode passion and death. The colours relate to Chinese symbolism and the male characters' names. Yellow echoes the jin or gold in Yang Jinshan's name. Green/blue/black relates to qing in Tianqing's name. White is bai in the name of the son, Tianbai, and symbolizes both moral purity and death. Red generally connotes masculinity, passion and marriage. In the initial scenes, Judou wears yellow (pink when she is being beaten) and the background is festooned with golden cloth. When she and Tianqing first see each other, bolts of yellow and red cloth have been ordered and Tianqing pours red dye into the vats of water, yang into yin. Yellow, red and blue-green cloth hang from the factory roof. In the scene where Judou seduces Tianqing, saying "Are you a man?...Am I wolf that will eat you?", Tianqing literally pounces but his face is erased from the screen. We see Judou's face panting in ecstasy as reams of newly dyed cloth, red for masculinity, plunge behind her into a dyeing vat of water (feminity). ${ }^{17}$ Applying Berry's analysis, the absence of Tianqing's face in the love-making scene suggests disharmony and indeed there is a quality of desperation in the love. But Tianqing is a man, he has a son. The son's birth and private marriage ceremony is happy. Judou wears red and they are now united within the frame. But once Tianbai is named and acknowledged by the ancestral clan as Yang Jinshan's son, the colours as a psychic barometer change to those of death. For example, when Tianqing and Judou steal outside to make love in the wild, it is a barren wilderness, not luxuriant growth as in Red Sorghum. They both wear black as they dry white lengths of cloth. They wear the same dark clothes in the tunnel where they finally steal away to make love, having been discovered even in the barren outdoors. They are already figuratively dead to society, buried illicitly in an underground covered coffin. 


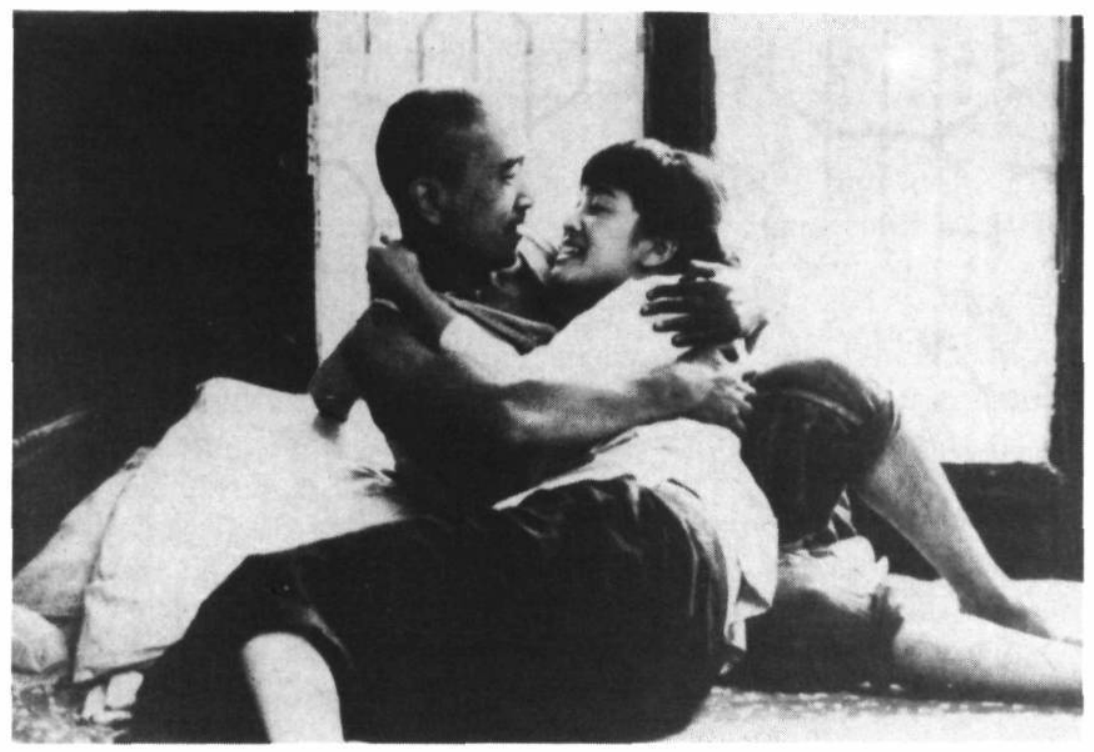

Judou de Zhang Yimou (1989)

Sexuality is ultimately defined, however, by images of disease and animality. The old man treats Judou worse than a mule; he actually cares for the mule when it is sick. Apart from Tianbai, the family call him lao dongxi, "an old thing", denying him the humanity he denies others. He puts Tianqing in the stable, where he spies on Judou washing through a narrow crack in the stable wall. When Judou realizes this, she displays her bruised and battered body, her face eroticized and panting, a grotesque parody of sexual ecstasy. Cinematically, this is a deliberate play with the Hollywood gaze which she manipulates for the only available male who cares for her. Unlike Red Sorghum, which celebrates a powerful masculine physique, Judou reveals and revels in the physical body of the abused heroine. Ascendant yang literally marks and batters the inferior yin. Tianqing is the opposite of Grandfather : he is physically concealed but, emotionally abused himself, he appears weak, timid and cowed. He may be potent but he is not powerful. In fact, except when the old man tries to kill his son, he is a wimp. This catalogue of disease extends further 
into the story. Unable to acknowledge their love, Judou undergoes abortions and we see her wracked with pain. She repeats the screams and the wish to die that she previously voiced with her husband. Finally the doctor says that she can have no more children: "she is rotten down there". Her incapacity and infertility now mirrors that of her legitimate husband. A sick sexuality, in the Chinese texts, causes actual sickness in people and the social order. The end is defilement and death. These deaths complete the sexual colour symbolism. Tianbai drowns both fathers in the dyeing vats, symbolic of an excess of yin. But there is a difference; Tianqing's death "replays" the seduction scene when reams of red cloth fall into the vat, a visual equation of marriage and death which is part of the language of this film. Judou burns down the factory and herself with it. Fire, as a male symbol, is here a deadly touch of symmetry. Judou dies in an excess of masculinity. The family, and therefore society, is in disorder and decline.

The Chinese arts of the bedchamber became general techniques into the modern period. It is clear they derived from early Daoism and, like the theories on family, law and government, were probably hierarchized in the Han Dynasty. But the precise influence of early Daoism, and its suggested origins in matriarchal cults, is unknown because of the loss of ancient texts. Foucault calls the transmitted art of the Orient an ars erotica which differs from the science of sex, scientia sexualis, in the West :

In the erotic art truth is drawn from pleasure itself, understood as a practice and accumulated as experience; pleasure is not considered in relation to an absolute law of the forbidden and permitted, nor by reference to a criterion of utility, but first and foremost in relation to itself. (Bush, 7) 18

Chinese erotic art does concentrate on the importance and techniques of sexual pleasure. But for women the absolute law of the father forbade adultery, which it allowed men, and prescribed severe legal penalties. Utility - health and longevity - was articulated in methods that benefited men in particular and were part of a medical, protoscientific discourse including diet, breathing and so on. But the prime "utility" was fertility: the "absolute law of the forbidden", was to be childless because the most unfilial act of all was to have no sons.

At the sexual level, in Red Sorghum and Judou, old husbands represent the "old father" and are devoid of masculine power. They bring disease and death. It is young men who are protective, potent and fertile. But empowerment depends on the system: in Red Sorghum humans are part of a cosmic, sometimes comic, rhythm whereas, in Judou, they are reduced to animals. Masculine 
sexuality, including fertility, is insufficient in Zhang Yimou's films. This masculinity must be publicly recognized at the family and social level. It must be legitimized.

\section{Patriarchy and Legitimacy : Fathers and Sons}

A sharp contrast [is] set up: between the wild, natural sexuality of women....and the tamed, social fertility (a "sacred, ancestral fertility controlled by men"). (Martin, 165)19

From field work in China, Martin argues that birth, marriage and death are gendered discourses in which male ideology celebrates the social and despises the biological. Women's experience is the inverse of men's: marriage in patriarchal ritual is symbolized by red for life, happiness and masculinity. Women, however, often explicitly lament marriage as death (179). As I have shown, such differences are encoded in the written language and suggested at the start of the films. But for both men and women the primary purpose of marriage was to produce sons. Martin suggests that, while the birth process is seen as dangerous and defiling, marriage "as the social event which legitimates it is seen by the male descent group....as a celebration of new life" (167).

This is also the case with the naming and "baptism" of the son into the patrilineal family at three years old. Ritual social birth, as distinct from the biological, is male. Again, we can see this in the written language. 20 Male ancestor is $z u$. The ancient form was a picture of a phallus, hence a phallus shaped ancestral tablet. The radical for spirit and ritual divination was added later. The word for female ancestor, $b i$, has no ritual attached. It is the pictograph for woman on the left and an ancient form of female genitalia on the right. Ancestry is social if male, biological if female. This patrilineal "birthing" ritual also informed patriarchal state power. China is known as zuguo, "land of the [male] ancestors". In Judou, a bastard son is legitimized by a "sacred, ancestral fertility controlled by men"; in Red Sorghum, a "natural" son is part of a "wild, natural" sexuality affirmed by the "God of Wine."

The whole point of these films is the absence or presence of patriarchal power as a legitimizing institution. The narrator / grandson in Red Sorghum tells us that his father was conceived in the wild sorghum; there was no official marriage but throughout Grandfather insists Jiu'er is his wife. Drunk, he repeats, "She is my wife, my wife!" Fertility is biological and unproblematic. Nine years later we see the son happily playing and inheriting his father's role; the urine in the wine is now his. Similarly, the rites 
to the God of Wine are both male and female. The god is male and Luohan directs the wine making with the wild product of the earth, sorghum, transformed through water and fire, yin and yang. $\mathrm{He}$ then leads the first ceremony to the Wine God.

$\begin{array}{ll}\text { Luohan : } & \text { Add cold water... } \\ \text { Luohan : } & \text { Fan the fire... } \\ \text { Luohan sings : } & \text { On the ninth of the ninth, we make new wine, } \\ \text { All sing : } & \text { From our hands, a wine so fine... } \\ & \text { Drink our wine, no coughs, full of } q i \text { from head } \\ & \text { to feet, } \\ & \text { Drink our wine, nurture yin } \text { and yang, a breath } \\ & \text { so sweet; } \\ & \text { Drink our wine, and dare to walk alone through } \\ & \text { Qingshakou, } \\ & \text { Drink our wine, before the Emperor do not bow, } \\ & \text { Drink our wine, } \\ & \text { One, four, seven; three, six, nine, } \\ & \text { On the ninth of the ninth, come back and follow } \\ & \text { me ... fine wine.21 }\end{array}$

Later, when Luohan is skinned alive by the Japanese we are told he did dare to die, dare not to kowtow, but cursed the Japanese. In a repeat of the wine ceremony to revenge Luohan's death, Jiu'er leads and her son takes the first ritual drink. The wine gives a living, health and male fearlessness but it is not an exclusively male god. And the wine which men make and drink is, of course, not only a homonym of Jiu'er's name but the new wine is made on her birthday, the ninth day of the ninth month which gave her the name, Nine, or Jiu'er.

But, most important, the grandson throughout calls the characters by their family names : Grandmother, Grandfather, Father. He is the historian, a millenia-long cultural task which simultaneously records and evaluates Chinese history. Evaluation is always moral: virtue and evil. In reconstructing the history of his grandparents, the grandson "praises" their bravery and lifestyle in a way which overturns traditional historical practice lauding "virtuous" officials, "virtuous" wives or heroic, but selfless, sexless, Party members. Virtue and heroism belong to the peasants, his male and female ancestors. The film redefines "virtue" outside the traditional family system or communist collective and within a "natural", nuclear family governed by feelings and productivity. Within this family, the names which describe biological relationships are accurate.

The accuracy, or "rectification" of names, is a major tenet of Confucianism. Rectify names, rectify relationships and thereby rectify the social order. In Judou, the "names" are wrong. In the beginning, Yang Jinshan is seated in front of the ancestral tablets. 
A visitor comments that Yang should buy Tianqing a wife because he is like a son to him. Yang throughout denies Tianqing the role of son, saying he is adopted and the terms are Uncle, Aunt, nephew. But Tianqing treats him like a "father" in the system and is "elder brother" to his own son who shares "Tian" in Tianqing's name signifying the same generation within a family line. The second part of their names compound the disorder. Qing and bai together, (qingqingbaibai) according to the male clan elders, literally mean "purity" but the film turns on the irony that the Yang family relations are abominably impure in any context. Although Tianqing thinks of killing his uncle / father in the night, he does not but saves his life. Later, when Judou suggests they kill him, he says, "He is still my uncle" even though Yang Jinshan has unsuccessfully tried three times to kill Yang Tianbai. Thus, the names indicate the familial and social confusion. Unlike Grandfather who insists Jiu'er is his "wife", Judou screams out to Tianqing who persists in loyalty to his uncle/father, "Then what am I to you? Tell me, what am I?". He cannot answer. Nor can he answer when he is asked to name Tianbai as his "brother" at the birthday party. He chokes on the words but can never admit his paternity. Even towards the end, when Judou tells Tianbai that Tianqing is his father, Tianqing calls out "Aunt!", in horror, legitimizing a patriarchal system which has absolutely delegitimized and dehumanized him.

It follows, with the "inexorable" logic which $\mathrm{Hu}$ attributes to Greek tragedy, that the son will delegitimize both "fathers" who have reared him in a sick system. First, he grows up unnaturally, never calling anyone by their names, never smiling. At the moment his "official" father tries to drown him, he turns and says his first word "Father" which he repeats again and again. When he allows Yang to drown in the same dyeing vat that Yang wanted to drown him, he smiles and then laughs with glee. In the funeral, he takes on the ancestral power that Yang called on to revenge their family name even though he is the most unfilial of all sons, having committed patricide, the most abominable of all crimes and punishable by "lingering death". He literally sits high up on the coffin, in white before a sign of "Yang Jinshan's spirit", as the coffin ritually "runs over" his father and mother forty-nine times.

This simultaneously sets up a naming ceremony, a celebration and a funeral. In Yang Jinshan's funeral procession, Yang Tianbai sits high on the coffin, holding a tablet saying "Ancestor Yang Jinshan". As a "filial son", he inherits Yang Jinshan's name and position, becoming a "new" father. The shot, filmed from below emphazises the tablet, and visually gives Tianbai a castrating 
In this story, it is the son who "castrates" the parents. He locks his father out of the house each day, a severely grim heir both to the "power of the father" and to Yang Jinshan's ancestral revenge. The system reveres death. The clan elders have enforced the "ancestral rules" to ensure the family names remains unsullied (qingbai is again repeated here) by committing Judou to chaste widowhood. It is Tianbai who enforces these rules and confines his mother in the factory.

This play around "names" and ancestral legitimacy is reinforced by patterns of behaviour repeated from generation to generation. Yang beats Judou, Judou hits Tianbai, Tianqing hits Judou and Tianbai savagely hits Tianqing. Yang, the severe father, is treated as a baby after he is crippled, occupying the same barrell which "cradled" Tianbai. Tianqing and Tianbai threaten others with cleavers. Tianbai drowns his fathers in the vat in which his "ancestral" father tried to drown him. He drowns Tianqing in the same coloured vat with the same red cloth that was backgrounded during his parents' lovemaking. Where parents are supposed to educate their children and expect filiality, he frequently stands alone and high up observing them together as a silent incarnation of unnatural but ancestral justice. Finally, he will not allow his parents to die in the tunnel after making love. He carries them out just as Tianqing once carried Yang Jinshan and was tempted to kill him. Tianbai dares to do what Tianqing hardly dares to think. Tianbai not only kills but beats his father when he tries to save himself. Beating, killing, carrying, crying: such actions, transmitted from generation to generation, are performed before the ancestral tablets, symbols of the "power of the father". The system has the sons it deserves; but the "names" are wrong and the system is perverted.

Thus, Red Sorghum and Judou present two pictures of two very different societies. As suggested, the opening scenes of nature and factory respectively mirror the family orders. One is a society based on natural and biological laws where relationships are warm, generous and nurturing. The motif tune is Grandfather's marriage song: "Sweetheart, bravely walk on...there are nine thousand, nine hundred and ninety-nine roads to heaven". Ma states that Grandfather "confronts a 'natural' but enclosed wilderness so that a new [social] order $(f a)$ is established through him" (Ma, 130). In Lu Xun's Darwinian framework, this society conforms to the law of nature and survival. In the other, a children's song is repeated throughout: "In Wang Village, there 
was a dog, the dog bites and there is nowhere to go but home." Judou wants to escape but, as Tianqing says, if they openly flaunt social rules they will be killed. Ma writes "the restricted space of 'father' and 'son' is surrounded by society at large. 'Ancestral rules' constantly intervene through white-bearded old men until, finally, these rules determine the story" (130). Borrowing Lu Xun again, this is a society which itself flouts all natural laws to maintain ancestral rules and must lead to death.

Death is the final indictment in both films. As in Yellow Earth, they close with the heroines' death, leaving men without women, yang without yin, a world reduced to chaos. But unlike many Chinese films in which girls and women are sacrificed or saved, raped or revenged, both Jiu'er and Judou die flamboyantly and heroically. Suicide in the Chinese system was not just escape, it was also accusation. The ghost could haunt the living and it publicly proclaimed abuse. It is no wonder then that so many women drowned themselves in the well, polluting the very livelihood of the village and calling in the repressive Chinese penal system. In Red Sorghum and Judou, the heroines' death is heroic accusation: Jiu'er dies fighting the Japanese (or, at least, taking the food to men fighting the Japanese) and Judou burns down the factory, the space which confined her. But they are nevertheless particularly female deaths. In Tragic ways of Killing a Woman, Loraux documents death as a gendered construct in Greek tragedy in which there were no words for female glory, only male renown. "And glory always makes the blood of women flow" (Loraux, 48). Female glory in China is "virtue" and glorious deaths are rendered in ways suitable to their gender. Both women die as wives and mothers. At the point when Jiu'er is shot in slow motion, her marriage tune is heard while her son shouts, "mother, mother" before he sings a ritual death song for her soul. Judou, in setting the factory alight, repeats her husband's attempt to kill the family and the film ends with the children's song: "nowhere to go but home". The son is absent. Men's actions, as fathers, husbands and sons, determine even how a woman kills herself.

This completes the picture of marriage as sons for fathers and death for women. They die engulfed in red flames, recalling the red confines of the bridal sedan for Jiu'er and the red cloth and dye for Judou. Jiu'er dies in the sorghum field which Zhang Yimou likened to a mother (Chen, 30) and symbolized "Nature, the Mother of All Things" for Daoists. Judou dies in the high-walled factory, the home of the ancestral shrine which is now destroyed as it destroyed her. Fire, red and passion: masculinity engulfs these women as it sears the screen. Above Jiu'er's dead body, the sun 
eclipses the moon, the world turns red, in sympathetic cosmic chaos. Around Judou's living body, decorated as if for a wedding, flames run through a palette from yellow, to orange, to crimson. Many critiques suggest these women in Zhang Yimou's films have some sort of "freedom", freedom to choose their men. But this choice is the only available young man in the diegesis as an alternative to death. As Loraux wrote of Greek tragedy:

They are free enough to kill themselves, but they are not free enough to escape from the space to which they belong, and the remote sanctum where they meet their death is equally the symbol of their life - a life that finds its meaning outside the self and is fulfilled only in the institutions of marriage and maternity, which tie women to the world and lives of men. (Loraux, 23)

Male fantasy and female nightmare. Either way, it is fathers and sons, and the social institutions they control from fertility to war, who decide women's births, marriages and deaths.

Red Sorghum and Judou suggest different orders of "father" and "son", Dionysian life or tragic death. But it is the "father", the socially sanctioned male authority, who decides women's lives and the "son" who judges them even in mythic idyll. Male culture controls female nature.

\section{Conclusion}

By interrogating masculinity in Zhang Yimou's film texts, and they are texts of the imaginary told through Chinese conventions, we come to some expected, some surprising conclusions. The expected is the May Fourth and Marxist critique of the patriarchal family as microcosm of the social order. The surprising is that behind the narrative and visual focus on one female lies a constant male presence which is varied, problematized and highly competitive. While these films may well offer new representations of women as sexually desiring subjects, they are not "masters of their destiny" as so many reviews suggest. 22 Their desire ultimately affirms particular men in competition with other men. For women, it is survival. For men, it is power presented through the grid of fathers and sons. In Zhang Yimou's fourth film (or "third personal film"), he talks about "man's curious obsession with doing battle...the deadly game to achieve or maintain superiority". In all three films, this "game" is played out through the family. 23

Indeed, like CEdipus Rex, the films begin and end with children. 24 Jiu'er is a daughter sold by her father; her son and grandson end the film. Judou begins with the nephew / son returning to his "old" father; a different son is the sole survivor at 
the end. But unlike Greek tragedy, there is no self awareness, no catharsis, no symbolic restoration of order. Rather, there is a sense that individuals cannot escape from the larger system which determines their lives. When talking of a Chinese feudal mentality, Zhang Yimou said that the oppressed are also accomplices to the tragedy - "there is no escape".25 Edipality is both a consequence of the system and an escape through patricide. But, except for Tianqing who never acknowledged his son and so did not himself deserve to be acknowledged as father, patricide is not murder of an actual father but of a symbolic "feudal" order. Patricide is the event which establishes the evil of a system which should be destroyed.

If œdipality is part of a Chinese feudal mentality, is it as Freud claimed of "universal validity"? (Freud, 101). And, in a Chinese context, may we make the next leap that it is universal because "it is the fate of all of us [he means men], to direct our first sexual impulse toward our mother and our first hatred and our first murderous wish against our father" (103)? Freud's reading of (Edipus omits that Laius, the father, insulted the gods whose curse led him to first try and kill his son. If Freud's literary analysis is speculative and suspect, 26 then many have equally queried the sexual "dogma" at the heart of his psychanalysis (for example Jung, 173). Jung claims Freud considers only "half of the whole" (for example,176) and, from a Chinese point of view, that half is masculinity. Nor does Freud account for the fact that "the sovereignty of the father", patriarchal authority, "is of social origin" (De Beauvoir, 69). If we turned the tables on the West and applied a Daoist reading to Freud, then œdipality is precisely a consequence of patriarchy, which is a social system. In generalizing the father's precedence over the mother, the young boy's identification with the father, the Freudian system mirrors and reifies a disharmony, a neurosis, at the core of patriarchy. Women are pale imitations of men's problems or they simply disappear. But in Daoism male and female are not opposites as subject and object. It is not even that they must allow equality. It is that they are complements embodying both yin and yang. Sickness and social disorder come from denying the yin in masculine sexuality and a male dominated social system. Men must recognize themselves.

It is this recognition that lies at the heart of Zhang Yimou's films. It is Freudian only in that it sees sexuality as a driving force in human nature. In China, human nature mirrors the natural world of which it is a part. In particular, it is the recognition of a disharmony, that "old" fathers disempower the young in the 
Chinese ancestral system, forcing submission and filial piety through legal and religious sanctions. For two millenia Daoism, in its various forms, has offered the most thorough political critique of patriarchy, male hierarchy and fixed gender constructs, and informed alternative views and other societies. It is still pœtically devastating when applied to modern China. In the West, Jung discovered Dao as unity (Jung, 234), finding the other half. Needham wrote: "perhaps the future belongs to their philosophy" (Needham, 152). Chinese are more practical. In Zhang Yimou's films, the problem is that the nurturing "new" father must first be the murderous son to perpetuate his new social order. Red Sorghum was very popular in China. The Party understandably banned Judou.

\section{Griffith University, Australia}

\section{NOTES}

1 This article originates from a paper delivered at the Third International Asian Cinema Studies Conference, New York University, 11-14 June 1992.

2 The film has now been released in China (August 1992).

3 This article, by a young lecturer at Beijing's film academy, is an excellent study. It is a pity it is not translated. My paper topic was put forward before I read Ma's article which confirmed or honed the argument in this essay. I have adopted his reading of "new" and "old" fathers as central to the films' meaning.

4 From Lu Xun, "Women Xianzai Zenme Zuo Fuqin," Lu Xun Quanji Vol 5 (1973) 117. Translated by Yang Xianyi and Gladys Yang,"What is required of Us as Fathers Today," Lu Xun, Selected Works (Beijing: Foreign Languages Press, 1980) 57.

5 Hu Jinquan, says Yin (Tiao), claims that Chinese tragedies stress both joys and sorrows with setbacks to the will created by the environment, while Greek tragedy is perversity linked to morals which leads to inexorable tragedy, such as patricide, matricide and killing one's wife. Judou's story is this sort of patricide.

6 She sees xiao as a key concept in the film which, in a Chinese cultural context, denotes the "root of oppression", p. 7.

7 "An Interview with Zhang Yimou", Raise the Red Lantern, Brochure distributed by ERA International, Taiwan, no date or pagination, Excerpted from an interview published in Esquire, Chinese edition, January, 1991.

8 Translated from Hong Gaoliang, Wanquan Taiben, Unpublished, henceforth referred to as Full Script, pp. 4-5.

9 For the best analysis see pp. 146-153. Sexual texts have a range of titles, such as The Dao of the Feminine (Yin Dao), The Immaculate Girl (Sunü Jing), who taught the Yellow Emperor methods of lovemaking, and Poetical Essay of Supreme Joy (Tiandi Yinyang Dale Fu).

10 For a discussion of Lu Xun's views on fathers and sons in a Social Darwinian context, see the analysis of "Women Xianzai Zenme Zuo Fuqin," 
Lu Xun Quanji Vol 5 (1973) in Farquhar, Mary. Children's Literature in China, unpublished doctoral thesis (Griffith University, 1988) 63-67. Lu Xun believed in China "we have many fathers of children, but in the future we want only lathers of men" (65). From Lu Xun, "Suigan Lu, 25," Lu Xun Quanji Vol 2.

11 Ma Junxiang in "Cong 'Hong Gaoliang' dao 'Judou'," Ershiyi shiji 7 (October 1991), makes this a central point of the films' political argument.

12 Also see Needham, Joseph, Science and Civilization in China. Vol II - History of Scientific Thought (Taipei : Xinyue Tushu Toufen Youxian Gongsi, 1969) 149.

13 A translated excerpt from the Huai Nan Zi (probably - 2nd century).

14 Full script, pp. 17-19.

15 Translated by Stacey Bush, unpublished, p. 10.

16 Bakken, George, "Never for the First Time : Society and Sexuality in Today's China," unpublished paper delivered at Australian National University, 8 May 1990, p. 6.

17 Kwok Wah Lau in "Judou - A Hermeneutical Reading of Crosscultural Cinema", has a very interesting cultural and semantic reading of Judou's sexual behaviour as yin, which means "an uncontrollable/excessive (flow of) torrent of water" and, by extension unacceptable sexual activity. She states this character is used "almost literally", in this scene, p. 6.

18 Quoted from Foucault, Michel, The History of Sexuality Vol 1: An Introduction, translated by Hurley, Robert (New York: Pantheon Books, 1978), p. 57.

19 Quote taken from Bloch, Maurice and Parry, Jonathan, "Introduction: Death and the Regeneration of Life" in Bloch and Parry, eds., Death and the Regeneration of Life (Cambridge : Cambridge University Press, 1982).

20 The analysis of these two characters is taken from Needham, Joseph, Science and Civilization in China. Vol II - History of Scientific Thought (Taipei : Xinyue Tushu Toufen Youxian Gongsi, 1969) 227.

21 Film Script, p. 46-47.

22 See, for example, "An Interview with Zhang Yimou", Raise the Red Lantern, Brochure distributed by ERA International, Taiwan, no date or pagination.

23 Ibid. This reading is supported by Zhang Yimou's third personal film - in 1988 he made an action-adventure Codename Cougar (Daihao Meizhoubao) - , Raise the Red Lantern (Da Hong Denglong Gaogao Gua, 1991 ) about which he said, "This film may be about women. And then again, it may not". The heroine's life revolves around rivalries with three other wives of the old master of the powerful Chen clan. The young son offers hope of escape but, in this film, nothing happens. She announces a sham pregnancy which is exposed and the red lanterns outside her private court, which if lit signify the husband's desire for that wife on that night, are permanently shrouded in black as a symbol of disgrace. The film ends with a new fifth wife looking out and seeing a now mad heroine walking about the courtyard. No lover, no son, no life. Without young men, women have no autonomy and no power.

24 Sophocles, "(Edipus the King" in Three Theban Plays, translated by Robert Fagles (New York : Viking Press, 1982) 139, 229. For an analysis see Seale, David, "Edipus the King : Blindness and Sight" in Seale, David, Vision and Stagecraft in Sophocles (London and Canberra : Croom Helm, 1982) $215,252-253$. For CEdipus' wife / mother's death, see 246-247. For 
Loraux's analysis, see Tragic ways of Killing a Woman (Cambridge, Mass., London : Harvard University Press, 1987) 14-15, 23-24, 51-52.

25 "An Interview with Zhang Yimou", Raise the Red Lantern, Brochure distributed by ERA International, Taiwan, no date or pagination.

26 See Storr, Anthony, Freud (Oxford, New York : Oxford University Press, 1989) 73-83 for a summary of Freud's work on art and literature.

\section{WORKS CITED}

Bakken, George. "Never for the First Time : Society and Sexuality in Today's China." Unpublished paper delivered at Australian National University (8 May 1990).

Berry, Chris. "Sexual Difference and the Viewing Subject in Li Shuangshuang and The Inlaws," in Berry, Chris, ed. Perspectives on Chinese Cinema. London : British Film Institute, 1991.

Beurdley, Michael, et al. Chinese Erotic Art. Translated from the French by Diane Imber. Fribourg : Chartwell Books, 1969.

Bodde, Derk and Morris, Clarence. Law In Imperial China. Taipei : Xinyue Tushu Toufen Youxian Gongsi, 1971.

Bush, Stacey. "Yellow Earth and Red Sorghum: An Approach to Reading the Ideology of Marriage and Politics of Desire." Unpublished honours thesis. Griffith University, 1991.

Chen Xiaoxin. "Lun 'Hong Gaoliang' de Wenhua Jiazhi." Dianying Yishu 199 (1989:2).

De Beauvoir, Simone. The Second Sex. Translated by H.M. Parshley. London : Jonathan Cape, 1956.

Farquhar, Mary. Children's Literature in China. Unpublished doctoral thesis. Griffith University, 1988.

Freud, Sigmund. "Edipus Rex," Woodward, Thomas, ed. Sophocles, Twentieth Century Views. Englewood Cliffs : Prentice-Hall, 1966.

Jung, C.G. Memories, Dreams, Reflections. Translated by Richard and Clara Wionston. Glasgow : William Collins \& Sons, 1980.

Kwok Wah Lau, Jenny. "Judou: A Hermeneutical Reading of Cross-cultural Cinema." Film Quarterly Vol 45 no 2 (Winter 1991-92).

Loraux, Nicole. Tragic Ways of Killing a Woman. Translated by Anthony Forster. Cambridge, Mass., London : Harvard University Press, 1987.

Lu Xun. "Suigan Lu, 25". Lu Xun Quanji Vol 2.

Lu Xun. "Women Xianzai Zenme Zuo Fuqin." Lu Xun Quanji Vol 5 (1973).

Lu Xun. "Wushiqi Xiandai de Tushazhe." Lu Xun Quanji Vol 2.

Ma Junxiang. "Cong 'Hong Gaoliang' dao 'Judou'." Ershiyi shiji 7 (October 1991) 123-132.

Martin. Emily. "Gender and Ideological Differences in Representations of Life and Death," Watson, James L. and Rawski, Emily S., ed. Death Ritual in Late Imperial and Modern China. Berkeley, Los Angeles, London : University of California Press, 1988.

Needham, Joseph. Science and Civilization in China. Vol II - History of Scientific Thought. Taipei : Xinyue Tushu Toufen Youxian Gongsi, 1969.

Qiu Kun. "Dalu Dianying Xiang Hequ Zou?" Zhengming 163 (1991:5). 
Reynaud, Bérénice. "China on the set with Zhang Yimou." Sight and Sound Vol 1 no 3 (July 1991).

Schak, David. Dating and Mate Selection in Modern Taiwan. Taipei : The Orient Cultural Service, 1974.

Storr, Anthony. Freud. Oxford, New York : Oxford University Press, 1989.

Wang, Yuejin. "Red Sorghum, Mixing Memory and Desire," in Berry, Chris, ed. Perspectives on Chinese Cinema. London : British Film Institute, 1991,pp. 80-103.

Woodman, Sophia. "Reforming the national character at the movies." An interview with Zhang Yimou. China Now 129 (Summer 1989).

Yin Tiao. "Hu Jinquan cheng 'Judou' shibu Dianxing Xila Beiju." Baixing 239 (May 1991).

Zhong Chengxiang. "'Hong gaoliang': Xinde Dianying Gaibian Guannian," Wenxue Pinglun Vol 4 (1988).

\section{GLOSSAIRE DES PRINCIPAUX TERMES CHINOIS (par ordre alphabétique)}

bi

Da hong denglong gaogao gua

da ziran

fa

fu zhi fa

hao

Hong gaoliang

jia

jia

jiu

Jiu'er

Judou

lao dongxi

ling

Lu Xun

nü

qingbai

qu

qu

shen
妣

大紅燈篭高高掛

大自然

法

父之法

好

紅高粱

家

嫁

酒

九兒

料豆

老東西

需

魯迅

女

青白

取

娶

神 
Tianbai

天白

Tianqing

天青

wuwei

xiao

無馜

xing

孝

xingjiao

yang

Yang Jinshan

性

性交

陽

yehe

yin

yin yang

yunyu

Zhang Yimou

zhenren

ziran

$\mathrm{zu}$

楊金山

野合

淫

㓌陽

雲雨

張㙯謀

真人

自然

祖

zuguo

祖圈 